\title{
TERMITE-REPELLENT WOOD EXTRACTIVES ${ }^{1}$
}

\author{
George N. Wolcott ${ }^{2}$
}

\section{INTRODUCTION}

The basic food requirements of insects are substantially the same as those of vertebrate animals. This is true regardless of how innutritious or indigestible the food substance may seem to us, for from it the insect organism must necessarily extract carbohydrates essential for activity, and proteins essential for growth and development. Unless restricted by custom or habit to some one food, insects choose the more nutritious, and woodeating insects choose the wood containing the most digestible nutrients.

Of the principal constituents of wood, lignin is entirely indigestible, and termites are almost unique in that the cellulose of wood becomes available to them because protozoans present in their alimentary tract can digest it. Upon the death of the protozoan, the cellulose is released and can be absorbed by the termite. But even though termites can thus assimilate more of the wood constituents than other wood-feeding insects, it cannot be clearly demonstrated that the dry-wood termites chose woods with a high cellulose content rather than those containing more lignin, or that this is one of the important. "Factors in the Natural Resistance of Woods to Termite Attack” (1) .

Indeed, the sapwood of every wood tested without exception is somewhat to very much more acceptable than is the heartwood, yet chemical analyses of numerous woods indicate that there is little if any more cellulose in the sapwood than in the heartwood. The marked preference for sapwood so universally shown by dry-wood termites is due rather to the presence here of such constituents as sugar, starch, and proteins, in considerably greater quantity than in the heartwood. Physiologically, the heartwood of the tree is inert and dead tissue, primarily useful to the tree for mechanical support, and is eaten by dry-wood termites only when none of the more nutritious sapwood is available.

As all of these desirable nutrients are necessarily present in all woods, the marked preference of termites for some kinds of woods, and their avoidance of others, depend upon the presence of minute amounts of other constituents which are definitely toxic or repellent. Because most wood chemistry deals with the conifers and softwoods used in pulp and paper

${ }^{1}$ A paper presented at the annual meeting of the American Society of Agricultural Sciences, San Germán, Puerto Rico, November 30, 1951.

${ }^{2}$ Entomologist and Head of the Department, Agricultural Experiment Station University of Puerto Rico, Río Piedras, P. R.

${ }^{3}$ Numbers in parentheses refer to Literature Cited, p. 227. 
production, and because these constituents are present in such small amounts, surprisingly little is known about them. Indeed, their detection and separation by the chemist require also the contemporary cooperation of the entomologist to prove their toxicity, or to determine that they are sufficiently objectionable to the insects to account for the immunity of the wood from insect attack.

Until recently the only known such wood constituent was derived from East Indian teakwood, Tectona grandis L.: beta-methylanthraquinone, or "tectoquinone". We may possibly question whether tectoquinone is really the vitally important and essential constituent responsible for the wellknown resistance of teakwood to rot, decay, and insect attack. Of the other quinones commercially available for test, none showed comparable repellent properties, and of tectoquinone itself, a concentration of at least 1-percent impregnated into flamboyán wood was required for permanent protection against dry-wood termite attack. By comparison with other comparable substances about to be mentioned this seems excessive.

\section{EXPERIMENTAL FINDINGS}

The wood of a Venezuelan tree locally called "ciezo" or "guaricamo", is not merely repellent to termites but so toxic that they die when confined with a small sample. The tree never attains a size to be used in construction or as a cabinet wood, but its extractive, called "ryanodine" by chemists in the research laboratories of Merck \& Co., (2) is commercially used as an insecticide. It was first sold under the trade name "Ryanex," but is now processed and handled by S. B. Penick \& Co., producers and manufacturers of other insecticides.

Ryanodine is soluble in acetone, and dilutions of one-fiftieth of 1 percent in which flamboyán samples were submerged for 10 minutes proved to be toxic to dry-wood termites for several weeks and prevented the attack of fresh termites for over 6 months. To date, 3 years later, similar samples impregnated with one-twentieth of 1 percent have not been eaten, and possibly this concentration will give permanent protection. Ryanodine has not been available for test as long as tectoquinone, but from these preliminary tests it appears to be approximately 20 times as effective against termites.

A short notice in Science mentioning the investigations being conducted by some of the smaller research institutions in Europe led to correspondence with Holger Erdtman, in charge of the Division of Organic Chemistry in the Royal Institute of Technology at Stockholm, Sweden. He was obtainining "heartwood extractives of conifers" (3) which had not been tested against termites, and indeed was experiencing the greatest difficulty in having them comparatively tested with any wood-eating insects. The minute 
amount of pinosylvin (3,5-hydroxystilbene) extracted from the heartwood of Scotch pine which he sent for preliminary trial proved to be much more toxic to termites than any chemical previously tested, and at one-hundredth of 1-percent concentration has continued to protect the treated sample of flamboyán wood against termite attack for over 15 months.

We do not know, indeed, how effective pinosylvin really is, for no tests at greater dilutions have been made, this being the minimum dilution at which any other chemical has been able to protect wood for even a few days. Erdtman wrote: "Pinosylvin and its mono- and dimethyl ether appear to be characteristic components of the heartwood of almost all pine species. These stilbene derivatives appear to be characteristic components of the genus Pinus". To date these other constituents have shown as great a resistance to termite attack as pinosylvin itself. Even the commercially available stilbene, although eaten in 11 months at one-hundredth of 1 percent concentration, has continued repellent to date at one-fiftieth of 1 percent.

The extractives obtained by Erdtman from other species of conifers less resistant to insect attack than is Scotch pine do not protect against termites: a result which might well be anticipated even before the tests had been made. But chlorophorin, a modified pinosylvin with a long chain attached, extracted by him from the tropical tree "mora", Chlorophora tinctoria (L.) Gaud., although failing to protect treated flamboyán wood at one-hundredth of 1 percent concentration, to date is uneaten at one-fiftieth of 1 percent. Chlorophorin is a dull greenish-brown powder, even the greatest concentrations of which do not stain flamboyán wood, and should not be confused with the dye, morin, the much better-known product of mora, which has no insecticidal properties.

West Indian mohogany, Swietenia mahagoni Jacquin, is not only a most beautiful and desirable cabinet wood, but its especial value in the Tropics depends upon its well-known resistance to dry-wood termite attack. Until very recently no chemist has attempted to find out why it is resistant, and I am proud in being able to announce that Conrado F. Asenjo of the School of Medicine of the University of Puerto Rico, has not only started work, but has progressed in his investigation and has already separated the crude material containing the hitherto unknown extractive.

He found that 2-percent sodium hydroxide solution extracted over a tenth of the weight of the mahogany, and that water extracted over 2 percent, but flamboyán samples submerged in these extractives were as attractive to dry-wood termites as if untreated. The extractives from mahogany obtained by hydrochloric acid and by acetone were only slightly less attractive, and obviously they did not contain the particular chemical which is the basis of the ability of mahogany to withstand dry-wood termite attack. All of these extractives were more or less purplish-brown, but this stain 
was not noticeable in the treated flamboyán wood. When the termites fed on these samples, however, the contents of their abdomens turned purple: as conspicuous an indication of what they had been eating as blackberry jam smeared around a small boy's mouth.

Ether petroleum extracted none of this purplish dye from mahogany, but its extractive was light yellowish in color, precipitating on standing a waxy white substance, which, at one-twentieth of 1 percent concentration entirely protected flamboyán wood from termite attack. Asenjo has thus obtained the vitally important extractive from mahogany; it still remains to ascertain whether this is one substance, or a mixture of several, and also to determine their chemical composition and properties.

\section{SUMMARY}

Jeither hardness nor high lignin content of a wood prevent its being eaten by dry-wood termites. Immunity from attack of so-called termiteresistant woods is due to the presence of some specific chemical constituent, such as tectoquinone in East Indian teak, in comparatively small amounts which causes it to be toxic or unpalatable to the insects. This substance extracted from the wood may be used as an insecticide, like commercial Ryania from Ryania speciosa, or for impregnating termite-susceptible woods to make them immune to termite attack. Conrado Asenjo of the local School of Medicine is working on the extractives of West Indian mahogany.

\section{RESUMEN}

Ni la dureza, ni el alto contenido de lignina de una madera evita que ésta pueda ser atacada por la polilla. La inmunidad de las llamadas maderas resistentes a la polilla proviene de algún constituyente químico específico, que hallándose comparativamente en pequeñas cantidades en ciertas maderas, las hace tóxicas, o por lo menos indeseables a los insectos. Un ejemplo puede ser la tectoquinona que se encuentra en la teca de la India Oriental.

Estas substancias, extraídas de la madera, pueden usarse como insecticidas, según se hace con la Ryania, la cual se origina de la Ryania speciosa. También pueden usarse para impregnar maderas susceptibles a la polilla para inmunizarlas contra los ataques de este insecto.

El Conrado Asenjo, de la Escuela de Medicina, se ha venido ocupando últimamente en extraer estas substancias de la caoba antillana.

\section{- LITERATURE CiTED}

1. Wolcott, G. N., Caribbean Forester, 7 (2) 121-34 1946.

2. Rogers, E. F., Koniuszy, F. R., and Folkers, Karl, Ryanodine: A new alkaloid from Ryania speciosa Vahl, J. Amer. Chem. Soc. 70 3086-8 1948.

3. Erdtman, Holger, Heartwood extractives of conifers: Their fungicidal and insectrepellent properties and taxonomic interest, J. Tech. Assn. Pulp and Paper Ind. 32 (7) 305-10 1949. 